\title{
Tarımsal ürünlerin pazarlanmasında hal kayıt sisteminin çiftçiler tarafından kullanılma durumu: İzmir ili örneği
}

\author{
The status of using wholesale market registration system by farmers in the marketing \\ of agricultural products: The case of Izmir province
}

\section{Filiz KINIKLIĐ, Hakan ADANACIOĞLU®, Cemile YILMAZ®, Gizem ÖZER®}

Ege Üniversitesi, Ziraat Fakültesi, Tarım Ekonomisi Bölümü, Bornova/İzmir

Sorumlu yazar (Corresponding author): F. Kınıklı, e-posta (e-mail): filiz.kinikli@ege.edu.tr

Yazar(lar) e-posta (Author e-mail): hakan.adanacioglu@ege.edu.tr, cemileylmz2@outlook.com,gzm.773@gmail.com

\section{MAKALE BILGİSİ}

Alınış tarihi 19 Şubat 2019

Düzeltilme tarihi 13 Mart 2019

Kabul tarihi 8 Nisan 2019

\section{Anahtar Kelimeler:}

Toptancı halleri

Kayıt sistemi

Çiftçiler

Tarim

Pazarlama

\begin{abstract}
öz
Sahip olduğu ekolojik özellikler nedeniyle Türkiye'nin, hemen hemen tüm tarım bölgelerinde açıkta meyve ve sebze üretimi yapılabilmektedir. Yaş meyve ve sebzelerin pazarlamasında en büyük rolü toptancı halleri ve bu hallerde görev alan komisyoncular üstlenmektedir. Toptancı hallerinde işlem gören sebze ve meyvenin, iç piyasaya sürülen sebze ve meyvenin yalnızca \%30'unu olușturduğu, \%70'inin ise kayıt dıșı olarak pazarlandığı yapılan çalıșmalarda ortaya konmuştur. Kayıt dişılık ne kadar fazla olursa ekonomik kayıp ve haksız rekabette o kadar fazla ortaya çıkmaktadır. Türkiye'de sebze ve meyvede kayıt dışılığı önlemek amacıyla 2012 yılında yürürlüğe giren 5957 sayılı yeni hal kanunu kapsamında hal kayıt sistemi uygulanmaya başlanmıştır. Bu çalışmanın amacı üreticilerin hal kayıt sistemini kullanımını ortaya koyarak, kayıt dışı ticareti miktar ve değer olarak tespit etmektir. Araștırmada gayeli kota örneklemes kullanılarak patates, mandalina ve şeftali üreticilerinden toplam 150 üretici ile görüşülmüştür. Çalışmada üreticilerin hal kayıt sistemi kavramını duyma oranının yüksek olduğu belirlenmiş fakat kayıt olma oranının yeterli düzeyde olmadığı sonucuna varılmıştır. Ayrıca sisteme kayıt olan üreticilerin bildirim yapma oranının oldukça düşük olduğu görülmüştür. 2017 y1lı için kayıt dıșılığın mandalinada $\% 15$, şeftalide $\% 8$ ve patateste $\% 1$ olduğu tespit edilmiștir. Bu sistemdeki en önemli sorun üreticilere hal kayıt sistemi ve işleyişi hakkında gerekli bilginin kurumlar tarafından verilmeyişidir. Bu kapsamda çiftçilere hal kayıt sisteminin ne demek olduğu, hal kayıt sistemine nasıl kayıt olunacağı ve nasıl bildirim yapılması gerektiğini açıklayan bilgilendirme amaçlı eğitim çalışmaları yapılmalıdır.
\end{abstract}

\section{ARTICLE INFO}

Received 19 February 2019

Received in revised form 13 March 2019

Accepted 8 April 2019

\section{Keywords:}

Wholesale markets

Registration system

Farmers

Agriculture

Marketing

\begin{abstract}
Due to ecological properties had by Turkey, fruit and vegetable production is grown in almost all agricultural areas. The significant role in the marketing of fresh fruits and vegetables belongs to wholesale food markets and wholesale market brokers. In the literature, it was determined that $70 \%$ of fresh vegetables and fruits were marketed as informal. If there is an informality in an economy, loss and unfair competition arises. In Turkey, the law no:5957 was gone into operation in 2012 and the new wholesale market law has been applied. The purpose of this study is to determine the usage status of the wholesale market registration system by farmers and to determine the informal trade. In this research, using Quota sampling the questionnaire was applied to potato, mandarin, and peach total of 150 farmers. In the study, it was determined that the rate of hearing the concept of the wholesale market registration system was high but the rate of registration was low. It is determined that farmers who were registered to the system the rate of notifying is very low. In the study, it was determined that the informal market was $15 \%$ in Mandarin, $8 \%$ in peach and $1 \%$ in potato. The most important problem in the wholesale market registration system is the lack of information about the farmers' wholesale market registration system and operation. In this context, informational training studies should be done to explain to farmers what the registration system means, how to register to the registration system and how to notify them.
\end{abstract}




\section{Giriş}

Türkiye'nin sahip olduğu ekolojik özellikler nedeniyle, hemen hemen tüm tarım bölgelerinde, açıkta meyve ve sebze üretim olanağı bulunabilmekte ve örtü altı sebze yetiştiriciliği de giderek yaygınlaşmaktadır. $\mathrm{Bu}$ nedenle, meyve-sebze üretimi, başta Ege, Akdeniz ve Marmara Bölgeleri olmak üzere, geniş bir üretici kesiminin geçim kaynağını oluşturmaktadır (Eraktan 1997).

Yaş meyve ve sebzelerin pazarlamasında en büyük rolü toptanc1 halleri ve bu hallerde görev alan komisyoncular üstlenmektedir. Ayrıca toptancı hallerinin ürünleri kayıt altına alması da önemli bir husustur. Kayıt dış1lık ne kadar fazla olursa ekonomik kayıp ve haksız rekabette o ölçüde ortaya çıkmaktadır.

Türkiye'de Toptancı Halleri, 1960 y1lında yürürlüğe giren 1580 sayılı Belediyeler Kanunu'nun 15. maddesine göre kurulmakta ve 16.05.1960 tarih ve 10605 say1lı Resmî Gazete'de yayınlanarak yürürlüğe giren 80 sayılı toptanc1 hallerinin yönetim şekli hakkındaki kanun hükümlerine göre, belediyelerin sorumluluğunda yönetilmektedir (Demirbaş 2001). Fakat yasadaki bazı boşluklardan dolayı, 27 Haziran 1995 tarihinde 'Yaş Sebze ve Meyve Ticaretinin Düzenlenmesi ve Toptancı Halleri Hakkında KHK 22326 sayılı Resmî Gazete'de yayınlanarak yürürlüğe girmiştir. $\mathrm{Bu}$ kanun hükmünde kararnameye göre 'Haller Yasası' olarak bilinen 4367 sayılı 'Yaş Sebze ve Meyve Ticaretinin Düzenlenmesi ve Toptanc1 Halleri Hakkında Kanun Hükmünde Kararnamenin Bazı Maddelerinin Değiştirilmesine Dair Kanun', 11.06.1998 tarihinde kabul edilerek, 14.06.1998 tarihinde 23372 sayılı Resmî Gazete'de yayınlanarak yürürlüğe girmiştir. Böylece 1995 yılında çıkarılan 552 sayılı KHK'de bazı değişikliklerle üç y1l sonra yasalaşmıştır (Giray 1998).

552 sayılı KHK'de genel olarak; yaş meyve ve sebzelerin alımı, satımı ve devri ile toptancı halleri ve pazar yerlerinin kuruluş, işleyiş, yönetim ve denetimlerine ilişkin esaslardan bahsedilmiştir. $\mathrm{Bu}$ kararname, üç temel esas üzerine kurulmuştur. Bunlar; yaş sebze ve meyvelerin öncelikle hallerde toplanması; serbest rekabet koşulları altında en uygun fiyat oluşumunun sağlanması ve denetimin geniş ölçüde belediyeler eliyle yürütülmesi şeklindedir (Sayın ve Mencet 2007). Canik ve Alparslan tarafından 2010 yılında yapılan bir çalışmada, 552 sayılık KHK'de yapılan değişiklilere rağmen kayıt dışılı̆̆ın önlenemediği belirlenmiştir. Yine aynı çalışmada toptancı hallerinde işlem gören sebze ve meyvenin, iç piyasaya sürülen sebze ve meyvenin yalnızca \%30'unu oluşturduğu ve \%70'inin kayıt dışı olarak pazarlandığı belirlenmiştir (Canik ve Alparslan 2010).

1 Ocak 2012'de 5957 say1l "Sebze ve Meyveler ile Yeterli Arz ve Talep Derinliği Bulunan Diğer Malların Ticaretinin Düzenlenmesi Hakkında Kanun" çıkarılmıştır. Bu kanun ile kayıtlı olmayan aracıların mümkün olduğu kadar ortadan kaldırılması, üreticilerin toptancı hallerine erişim maliyetlerinin azaltılması ve çiftçilerin ürünlerini doğrudan perakendecilere satabilmeleri hedeflenmiştir (Aysoy ve ark. 2015). Adanacıŏlu ve Yercan tarafindan 2012 yılında yapılan bir çalışmada, Yeni Hal Kanununun yürürlüğe girmesine rağmen kayıt dış1 işlemlerin önlenemediği, yaş meyve ve sebze ticaretinde toptanc1 hallerinin müzayede, depolama, tasnifleme ve ambalajlama tesisleri ile laboratuvar ve soğuk hava deposu gibi alt yapı eksiklikleri nedeniyle pazarlama ve yardımcı hizmetleri yerine getirmede işlevsiz kaldığı, gıda güvenilirliğinin ihmal edildiği, kayıt dışılığa bağlı olarak rekabet şartlarının oluşturulamadığı, üretici ile tüketici arasındaki pazarlama marjının oldukça yüksek olduğu ve bunun giderek arttığ belirtilmiştir (Adanacıŏlu ve Yercan 2012).

Literatürde yapılan diğer çalışmalar incelendiğinde; farklı illerde toptanc1 hallerinin durumu ve işleyişi, yeni hal yasası hakkında komisyoncu görüşleri ve uygulamada karşıllaşı1lan sorunların ortaya konulduğu çalışmalara rastlanmıştır (Yılmaz ve Y1lmaz 2002; Hadimli ve Bulut 2004; Canik ve Alparslan 2010; Gözener ve Sayılı 2011; Çoşkun 2014; Çoşkun ve Tunalıoğlu 2015; Aydın Can ve Engindeniz 2018). Bununla birlikte; yeni hal kanunu ile daha önceki yasal düzenlemelerin karşılaştırılarak incelendiği, avantaj ve dezavantajların ortaya konulduğu, muhasebe bilgi sistemi ve hallerdeki belge düzeninin işlenişi gibi konuları ele alan ikincil veri taraması ile hazırlanmış çalışmaların literatürde önemli bir yere sahip olduğu görülmüştür (Adanacioğlu ve Yercan 2012; Ölmez ve Demirörs 2015; Apalı ve Bozcu 2018).

$\mathrm{Bu}$ çalışma ile; İzmir ilindeki yaş meyve ve sebze üreticilerinin 5957 sayılı Yeni Hal Kanunu hakkında bilgi düzeylerinin belirlenmesi, kayıt dışı ticaretin ve üreticilerin Hal Kayıt Sistemine bakış açılarının ortaya konulması amaçlanmıştır. Böylece litaratüre Yeni Hal Kanunu hakkında üretici görüşlerinin de ortaya konulduğu ve üreticilerin karşılaştıkları sorunlara yönelik kayıt dışılık hakkıında somut bilgilerin yer aldığ 1 bir çalışma eklenmiş olacaktır.

\section{Materyal ve Yöntem}

$\mathrm{Bu}$ çalışmanın ana materyalini, İzmir ilinde yaş meyve ve sebze üretimi yapan üreticiler ile yüz yüze yapılan anketlerden elde edilen veriler oluşturmaktadır. Ayrıca, önceden yayınlanmış tezler, araştırmalar, makaleler, bildiriler, proje raporları vb. çalışmanın ikincil veri kaynaklarını oluşturmaktadır.

Araştırmanın kapsamına giren ürünleri belirlemek amacı ile İzmir Büyükşehir Belediyesinin Kaynaklar Yaş Meyve ve Sebze Haline başvurulmuştur. $\mathrm{Bu}$ kapsamda halde en fazla işlem yapılan ürünler tespit edilmiştir. Buna göre halde en fazla satışı olan ürünlerin patates, şeftali ve mandalina olduğu belirlenmiştir. $\mathrm{Bu}$ ürünlerin en fazla üretiminin gerçekleştirildiği; Ödemiş, Menderes ve Kemalpaşa ilçelerinde araştırma yürütülmüştür. Çalışmada gayeli kota örneklemesi yöntemi kullanılarak ele alınan 3 ürün için 50'şer üretici ile görüşülerek, toplam 150 anket yapılmıştır.

Anket yoluyla toplanan veriler, gerekli kodlamalar ve kontroller yapıldıktan sonra Excel, SPSS ve Gretl paket programına girilmiştir. Elde edilen veriler temel tanımlayıcı istatistikler kullanılarak çizelgeler halinde özetlenmiştir. Sürekli değişkenler için Kolmogorov Smirnov testi ile normal dağ 1 lım testi yapılmıştır. Normal dağılış gösteren değişkenler için varyans analizi, normal dağılış göstermeyen değişkenler için Kruskal Wallis testi uygulanarak patates, mandalina ve şeftali üreticileri arasındaki fark ortaya konulmuştur. Üreticilerin hal kayıt sistemine kayıt olma, bildirim yapma gibi bazı özellikleri ise ki-kare analizleri ile değerlendirilmiştir. Üreticilerin hal kayıt sistemine ilişkin sorunları ise Best-Worst analizi ile ortaya konulmuştur. Üreticilerin hal kayıt sistemine kayıt olmasını etkileyen faktörler lojistik regresyon yöntemi ile analiz edilmiştir. Modelde bağımlı değişken olarak hal kayıt sistemine kayıt olma temel alınmıştır. Eğer üretici hal kayıt sistemine kayıt oluyorsa Y: 1, olmuyorsa Y: 0 olarak alınmıştır. Bağımsız değişken olarak ise; üreticinin yaşı (yıl), eğitimi (sadece okuma yazma bilen: 0, İlkokul: 1, Ortaokul: 2 Lise: 3, Üniversite: 4 
Yüksek lisans/doktora: 5), toplam arazi (dekar), yıllık gelir (TL), ailedeki birey sayısı, köyün ilçeye uzaklığı $(\mathrm{km})$, internete bağlanma (bağlanan: 1, bağlanmayan: 0), bilgisayar kullanma (kullanan: 1, kullanmayan: 0), tarım dış1 işi olma (olan: 1, olmayan: 0 ) ve akıllı telefona sahip olması (var: 1, yok: 0 ) ele alınmışır.

\section{Bulgular}

\section{1 Üreticiler ile İlgili Bulgular}

Araştırma kapsamında patates, mandalina ve şeftali üretimi yapan 150 üretici ile görüşülmüş ve üreticilerin yaş ortalamasının 46.95 olduğu belirlenmiştir. Mandalina üreticilerinin yaş ortalamasının, patates ve şeftali üreticilerinin yaş ortalamasına göre daha yüksek olduğu görülmüştür. Normal dağılım gösterdiği belirlenen yaş kriteri için gruplar arasında istatistiksel olarak anlamlı bir fark olup olmadığının belirlenmesi için varyans analizi uygulanmıştır. Gruplar arasındaki fark $\mathrm{p} \leq 0.05$ için anlamlı olduğu tespit edilmiştir. Üreticilerin genel olarak eğitim düzeyinin ilköğretim seviyesinde olduğu tespit edilmiştir. Üreticilerin hane halk1 büyüklüğ̈̈ ise ortalama 3.68 kişidir. 2016 y1lı ortalama hane halk1 büyüklüğü incelendiğinde Türkiye ortalamasının 3.48 , İzmir ili ortalamasının ise 3.04 kişi olduğu görülmüştür (İzmir Valiliği 2017). Araştırmanın kırsal alanda yapılmasından dolayı üreticilerin hane halkı büyüklüğünün İzmir ili ortalamasının üzerinde olması beklenen bir durumdur. Üreticilerin ailelerinde tarımla uğraşan kişi sayısı yaklaşı 2 birey ve bu üreticilerin ortalama 26 yıl tarımsal faaliyetle uğraştığı tespit edilmiştir. Ailede tarımla uğraşan kişi sayısı ve tarımsal deneyim süresine göre üreticiler arasında istatistiksel olarak anlamlı farklılıklar mevcuttur (Çizelge 1).

\section{2. İşletmelerin Yapısal Özellikleri}

İzmir Tarım İl Müdürlüğ̈̈'nden alınan bilgilere, göre İzmir ilinde patates üretiminin en fazla yapıldığı yer Ödemiş, mandalina üretiminin en fazla yapıldığ 1 yer Menderes, şeftali üretiminin en fazla yapıldığı yer ise Kemalpaşa ilçeleridir. Çizelge 2'de işletmelere ait bazı özellikler yer almaktadır. Buna göre; patates üreticileri yaklaşı 3 parselden oluşan ortalama 68.11 dekar alanda üretim faaliyetlerini sürdürmektedirler. Ödemiş ilçesinde patates üreticileri ile yapılan bir başka çalışmada benzer sonuçlara rastlanmıştır (Ormeci Kart ve ark. 2017). Patates üreticilerinin yıllık toplam patates üretim miktarı ise yaklaşık 373 tondur. Üreticilerin \%40'1 geleneksel olarak üretim yaptıklarını \%32'si organik ve \%28'i iyi tarım uygulamaları şeklinde üretim yaptıklarını belirtmişlerdir. Yöredeki bazı patates üreticilerinin organik tarım kapsamında sürekli denetim uygulanmasından dolayı organik tarım yapmasalar dahi üretim yöntemi olarak organik olduğunu belirtmişlerdir. Bunun bir diğer göstergesi de organik üretim ve ürün fiyatlarının birbiriyle uyuşmamasıdır. T.C. Gümrük ve Ticaret Bakanlığı'nın Hal Kayıt Sistemi sayfasında halde satışı yapılan geleneksel üretim yöntemi kullanılan patates ürününün ortalama satış fiyatı $0.70 \mathrm{TL} \mathrm{kg}^{-1} \mathrm{dir}$ (11.05.2018 tarihli veriler kullanılmıştır). Araştırma kapsamında görüşülen patates üreticilerinin beyanlarına göre ise ortalama patates fiyatı 0.44 $\mathrm{TL} \mathrm{kg}^{-1}$ dir. Üreticiler patatesin büyük bir kısmını ortalama 0.41 $\mathrm{TL} \mathrm{kg}^{-1} \mathrm{e}$ komisyoncuya sattıklarını belirtmişlerdir. Bunun dışında sanayiciye, tüccara ve doğrudan tüketiciye satış yapan üreticilerde bulunmaktadır.

Çizelge 1. Üreticilerin genel özellikleri.

Table 1. General features of farmers.

\begin{tabular}{|c|c|c|c|c|c|}
\hline & & Patates Üreticileri & Mandalina Üreticileri & Şeftali Üreticileri & Genel \\
\hline \multicolumn{2}{|l|}{ Yaş* } & 48.06 & 50.56 & 47.22 & 46.95 \\
\hline \multicolumn{2}{|l|}{ Eğitim (Yıl) } & 8.36 & 8.10 & 9.08 & 8.51 \\
\hline \multicolumn{2}{|c|}{ Ailedeki birey sayısı } & 3.68 & 3.80 & 3.56 & 3.68 \\
\hline \multicolumn{2}{|c|}{ Ailede tarımla uğraşan birey sayısı** } & 1.56 & 1.20 & 1.74 & 1.50 \\
\hline \multicolumn{2}{|c|}{ Tarımsal deneyim süresi** } & 27.84 & 28.36 & 21.80 & 26.00 \\
\hline \multirow[t]{5}{*}{ Y1llık Gelir (\%) } & 5000TL'den az & 12.0 & - & - & 4.0 \\
\hline & $5000-9999$ & 4.0 & - & 6.0 & 3.30 \\
\hline & $10000-14999$ & 12.0 & 4.0 & 4.0 & 6.70 \\
\hline & 15000-19999 & 12.0 & 16.0 & 18.0 & 15.30 \\
\hline & 20000 ve üstü & 60.0 & 80.0 & 72.0 & 70.70 \\
\hline
\end{tabular}

*Varyans analizine göre gruplar arasındaki fark $\mathrm{p} \leq 0.05$ için anlamlıdır. **Kruskal-Wallis testine göre gruplar arasındaki fark $\mathrm{p} \leq 0.05$ için anlamlıdır.

*According to Variance Analysis, the difference between the groups was found to be significant for $\mathrm{p} \leq 0.05$. **According to Kruskal-Wallis test, the difference between the groups was found to be significant for $\mathrm{p} \leq 0.05$.

Çizelge 2. İşletmelere ait özellikler.

Table 2. Features of farms.

\begin{tabular}{llccc}
\hline & & Patates Üreticileri & Mandalina Üreticileri & Şeftali Üreticileri \\
\hline Üretim alanı (daa)** & 68.11 & 39.54 & 25.12 \\
Parsel sayısı (adet)** & 3.08 & 2.90 & 2.88 \\
Toplam üretim miktarı (ton)** & & 373.25 & 171.10 & 80.40 \\
Ürün satıș fiyatı (TL kg (1) $^{* *}$ & & 0.44 & 0.98 & 1.23 \\
Üretim yöntemi (\%) & Geleneksel & 40.0 & 60.0 & 26.0 \\
& Organik & 32.0 & 14.0 & 8.0 \\
& İyi tarım & 28.0 & 26.0 & 66.0 \\
\hline
\end{tabular}

**Kruskal-Wallis testine göre gruplar arasındaki fark $\mathrm{p} \leq 0.05$ için anlamlıdır.

**According to Kruskal-Wallis test, the difference between the groups was found to be significant for $\mathrm{p} \leq 0.05$. 
Araştırma kapsamında görüşülen mandalina üreticileri yaklaşı 40 dekar alanda 171 ton mandalina üretimi gerçekleştirmektedirler. Üreticilerin \%60'1 geleneksel üretim yapmakta ve üretimini yaptıkları mandalinayı ortalama 0.98 $\mathrm{TL} \mathrm{kg}^{-1} \mathrm{e}$ satmaktadırlar. Bu fiyatın, T.C. Gümrük ve Ticaret Bakanlığı'nın Hal Kayıt Sistemi sayfasında halde satışı yapılan geleneksel üretim yöntemi ile üretilen mandalinanın ortalama satış fiyatının (1.48 TL kg-1) altında olduğu görülmüştür. Üreticiler mandalinayı genellikle tüccara ve doğrudan tüketiciye satarak pazarlamaktadırlar. Üreticiler mandalinanın tüccara satış fiyatının ortalama $0.94 \mathrm{TL} \mathrm{kg}^{-1}$ ve doğrudan tüketiciye satış fiyatının $1.42 \mathrm{TL} \mathrm{kg}^{-1}$ olduğunu belirtmişlerdir.

Şeftali üreticileri yaklaşık 3 parselden oluşan, 25.11 dekar alanda 80 ton şeftali üretimi yapmaktadırlar. Şeftali üreticilerinin \%66 gibi büyük bir kısmının iyi tarım uygulamaları yöntemiyle üretim yaptıkları belirlenmiştir. Üreticiler ürün satış fiyatının ortalama $1.23 \mathrm{TL} \mathrm{kg}^{-1}$ olduğunu ifade etmişlerdir. Patates ve mandalinada olduğu gibi üreticiler tarafından beyan edilen şeftali fiyatının da T.C. Gümrük ve Ticaret Bakanlığı'nın Hal Kayıt Sistemi sayfasında yer alan şeftali fiyatının (2.66 TL kg-1) altında olduğu tespit edilmiştir. Üreticilerin sıklıkla kullandıkları pazarlama kanallarının; komisyoncu, tüccar, pazarc1, doğrudan tüketici ve ihracatçı olduğu belirlenmiştir. Araştırma kapsamında görüşülen üreticiler, kullandıkları pazarlama kanalları içerisinde ürünü en yüksek fiyattan ihracatçıya sattıklarını belirtmişlerdir (yaklaşık $1.97 \mathrm{TL} \mathrm{kg}^{-1}$ ) (Çizelge 2). Antalya ilinde yapılan benzer bir çalışmada da sera sebzesi üreten üreticilerin öz tüketim dışında kalan ürünlerini komisyoncu aracıllı̆̆ ile sattığ 1 tespit edilmiştir (Yılmaz ve Yılmaz 2002). Aydın ilinde komisyoncularla yapılan bir başka çalışmada da, komisyoncuların \%89.5'inin doğrudan üreticiden ürün aldığı belirlenmiştir (Çoşkun 2014).

\section{3. Üreticilerin Hal Kayıt Sistemine Yönelik Bakış Açıları ve Bilgi Düzeyleri}

Araştırma kapsamında görüşülen üreticilerin \%68.7’si “Hal Kayıt" kavramını daha önce duyduklarını ifade etmişlerdir. "Hal Kayıt" kavramını duyma oranı şeftali üreticilerinde, patates ve mandalina üreticilerine göre oldukça yüksektir. Patates, mandalina ve şeftali üreticileri ile hal kayıt kavramını daha önce duyma durumu arasında istatistiksel olarak anlamlı bir fark olduğu tespit edilmiştir (Person Chi Square 6.941, p $0.031<0.05)$. Üreticilerin genel olarak \%68.7'si daha önce hal kayıt kavramını duyduğunu belirtmelerine rağmen hal kayıt sistemine kayıt olan üreticilerin oranı $\% 43$.3'tür. Bu oranın \%26 ile en düşük mandalina üreticilerinde olduğu tespit edilmiştir.
Bunu patates ve şeftali üreticileri takip etmektedir. Şeftali üreticilerinin $\% 82$ gibi büyük bir kısmının hal kayıt sistemi kavramını bilmelerine rağmen sisteme kayıt olma oranının $\% 68$ 'de kalması dikkat çekicidir. Öyle ki hal kayıt sistemine üreticiler internetten veya ak1llı telefon uygulamasından kendileri kayıt olabileceği gibi kooperatif veya birlik aracılığı ile kayıt olabilmektedir. Bunun yanında komisyoncular ve tüccarlar aracılığı ile de sisteme kayı olma imkânları bulunmaktadır. Patates, mandalina ve şeftali üreticileri ile hal kayıt sistemine kayıt olma arasında istatistiksel olarak anlamlı bir fark olduğu tespit edilmiştir (Person Chi Square 19.602, p $0.000<0.05)$ (Çizelge 3).

Patates üreticilerinin \%28'i, mandalina üreticilerinin \%16's1 ve şeftali üreticilerinin \%42'si Hal Kayıt Sistemine bildirim yaptıklarını belirtmişlerdir. Şeftali üreticilerinin patates ve mandalina üreticilerine göre daha fazla bildirim yaptıkları saptanmıştır. Araştırma kapsamında görüşülen üreticilerin hal kayıt sistemine bildirim yapma durumlarına göre gruplar arası değişim istatistiksel olarak anlamlı bulunmuştur (Person Chi Square 8.281, p 0.016<0.05). Genel olarak durum incelendiğinde; üreticilerin, \%28.7'si Hal Kayıt Sistemine bildirim yaptıklarını, \%71.3'lük kısım ise bildirim yapmadığını belirtmiştir (Çizelge 3). Hal kayıt sistemine bildirim yapan üreticilerin, \%32.6's1 Hal'e doğrudan başvuru, \%7.8'i çağrı merkezi, \%18.6's1 internet (E-Bildirim), \%7'si ak1llı telefon uygulamas1, \%32.6's1 komisyoncu aracılığ1 ve \%2.3'ü tüccar aracılığı ile Hal Kayı Sistemine bildirim yaptıklarını belirtmişlerdir. Bildirimde bulunmayan üreticilerin ise büyük bir kısmı bilgisi olmadığı ve uğraşmak istemediği için bildirimde bulunmadığını belirtmiştir. Bildirimde bulunmayan üreticilerin \%51.3'ü kendi adlarına hal kayıt sistemine satış bildirimi yapıldığını bildiklerini \%48.7'sinin ise kendileri adına hal kayıt sistemine bildirim yapılıp yapılmadığını bilmedikleri belirlenmiştir. Genel olarak üreticilerin adına komisyoncu ve tüccarların sisteme kayıt yaptı̆̆ 1 saptanmıştır.

Hal kayıt sistemine bildirim yaptığını ifade eden üreticilere, 2016 ve 2017 yılları için üretim miktarları ve hal kayıt sistemine bildirim yaptıkları miktarlar sorulmuştur. $\mathrm{Bu}$ soruyu patates üretimi yapan üreticilerin yalnızca \%28'i yanıtlamıştır. Buna göre; 2016 yılında üretilen patatesin tamamı hale bildirilirken, 2017 yılında yaklaşık 3 ton patatesin bildiriminin yapılmadığ saptanmıştır. Mandalina üretimi yapan üreticilerin de bu soruyu yanıtlama oranı yalnızca \%16'dır. Bu üreticilerin beyanlarına göre; mandalinada 2016 y1lında 16.67 ton, 2017 y1lında ise 25 ton kayıt dışı ürünün pazarlandığı görülmektedir. Şeftali

Çizelge 3. Üreticilerin hal kayıt sistemi kavramını duyma, kayıt olma ve bildirim yapma durumu (\%).

Table 3. Knowing the wholesale market registration system by farmers, registration and notification status of farmers (\%).

\begin{tabular}{|c|c|c|c|c|c|}
\hline & & $\begin{array}{c}\text { Patates } \\
\text { Üreticileri }\end{array}$ & $\begin{array}{l}\text { Mandalina } \\
\text { Üreticileri }\end{array}$ & Şeftali Üreticileri & Genel \\
\hline \multirow{2}{*}{ Hal Kayıt Sistemi Kavramını Duyma* } & Evet & 66.0 & 58.0 & 82.0 & 68.7 \\
\hline & Hayır & 34.0 & 42.0 & 18.0 & 31.3 \\
\hline \multirow{2}{*}{ Hal Kayıt Sistemine Kayıt Olma** } & Evet & 36.0 & 26.0 & 68.0 & 43.3 \\
\hline & Hayır & 64.0 & 74.0 & 32.0 & 56.7 \\
\hline \multirow[t]{2}{*}{ Hal Kayit Sistemine Bildirim Yapma*** } & Evet & 28.0 & 16.0 & 42.0 & 28.7 \\
\hline & Hayır & 72.0 & 84.0 & 58.0 & 71.3 \\
\hline \multirow[t]{6}{*}{ Hal Kayıt Sistemine Bildirim Yapma Şekli } & Hale Doğrudan & 28.6 & 25.0 & 38.1 & 32.6 \\
\hline & Çağrı Merkezi & 7.1 & 12.5 & 4.8 & 7.8 \\
\hline & E-Bldirim & 7.1 & 50.0 & 14.3 & 18.6 \\
\hline & Ak1llı Telefon & 21.4 & - & - & 7.0 \\
\hline & Komisyoncu & 35.7 & - & 42.9 & 32.6 \\
\hline & Tüccar & 28.6 & 12.5 & - & 2.3 \\
\hline
\end{tabular}

* Person Chi Square 6.941, p 0.031<0.05. **Person Chi Square 19.602, p 0.000<0.05. ***Person Chi Square 8.281, p 0.016<0.05. 
üreticilerinin ise \%48'i sorulan soruyu cevaplamıştır. 2016 y1lında Hal'e bildirilmeyen şeftali miktarı 8.27 ton iken, bu miktar 2017 yılında 5.36 tona düşmüştür. Buna göre; 2017 yılında en fazla kayıt dışı olarak pazarlanan ürünün $\% 14.55$ oranla mandalina olduğu tespit edilmiştir. Mandalinayı \%7.30 ile şeftali, \%0.49 ile patates takip etmektedir (Çizelge 4). Apalı ve Bozcu tarafindan 2018 yılında Antalya ilinde komisyoncular ile yapılan bir çalışmada, kayıt dışılığı kanıtlar nitelikte sonuçlara rastlanmıştır. Öyle ki komisyoncular tarafindan üreticiden alınan ürünün belgelendirilerek hale bildirilmesi gerekmektedir. Fakat yapılan çalı̧̧mada, gerçek usulde vergilendirilen müstahsiller tarafından hale satılmak üzere getirilen mallar için Fatura-2 belgesi düzenlendiği tespit edilmiştir. $\mathrm{Bu}$ durum gerçek usulde vergiye tabi olan müstahsillerin tüm belge düzenleme yetkisi komisyoncuya bırakıldığı için bu malları belgeleyememe sorunundan kaynaklanmaktadır. Fakat Fatura-2 belgesi Vergi Usul Kanununda düzenlenmiş bir belge olmadığından, bu belgenin kullanılması kanunen yok hükmünde sayıldığı için kayıt dışılık ortaya çıkmaktadır (Apalı ve Bozcu 2018).

Üreticilerin ürün satışı yaptığı alıcıların hal rüsumu adı altında para alma durumu incelendiğinde; patates üreticilerin $\% 14$ 'ü, mandalina üreticilerinin $\% 12$ 'si ve şeftali üreticilerinin $\% 38$ 'i satışlarını yaptıkları ürünlerin alıcıları tarafından hal rüsumu adı altında para aldıklarını belirtmişlerdir. Patates, mandalina ve şeftali üreticileri ile alıcıların hal rüsumu adı altında para alma durumu arasında istatistiksel olarak anlaml bir fark olduğu tespit edilmiştir (Person Chi Square 12.474, p $0.002<0.05)$.

Hal rüsumu adı altında para ödediğini ifade eden üreticilerin \%75'i tamamını kendisinin ödediğini belirtmiştir. $\mathrm{Bu}$ oran şeftali üreticilerinde \%89.5'tir.

Yeni hal kanununa göre, üretici örgütlerince (kooperatif, üretici birliği, vb.) toptancı hali içinde ve dışında satılan mallarda, organik veya iyi tarım kapsamında sertifikalandırdıkları ürünlerde ve üreticilerin ürettikleri ürünü doğrudan tüketicilere pazarladıklarında hal rüsumundan muaf olmaktadırlar. Üreticilere bu durum hakkında bilgi sahibi olup olmadıkları sorulduğunda, üreticilerin büyük çoğunluğunun böyle bir muafiyetten haberdar olmadıkları görülmüştür.

Araştırma kapsamında görüşülen üreticilere "Ürün Künyesi” kavramını bilip bilmedikleri sorulmuştur. Buna göre; patates üreticilerinin $\% 62$ 'si, mandalina üreticilerinin $\% 46$ 's1, şeftali üreticilerinin \%46'sı ürün künyesi kavramını bildiklerini belirtmişlerdir. Üretici grupları ile ürün künyesi kavramını bilme durumu arasında istatistiksel olarak anlamlı bir fark bulunamamıştır (Person Chi Square 3.416, p 0.181>0.05). "Ürün Künyesi" kavramını bilen üreticilerin ürün künyesine sahip olup olmadığı sorulduğunda ise $\% 76.3$ gibi büyük bir çoğunluğunun ürün künyesine sahip olduğu belirlenmiştir. Bu oran \%95.5 ile en yüksek şeftali üreticilerindedir (Çizelge 5).

Üreticilerin hal kayit sistemi konusunda en önemli ve en önemsiz gördükleri sorunlar Best-Worst Analizi ile ortaya konulmuştur. Anket katılan üreticilere göre, hal kayıt sistemi hakkında en önemli sorun "Üreticilerin bu sistem hakkında bilgisinin olmaması ve bilgi eksikliği” olarak saptanmıştır. En önemsiz sorun ise, "Hükümetin haller için uygulamaya çalıştı̆̆ mevzuatta sürekli değişim yaşanması" olduğu saptanmıştır (Çizelge 6). Bu çerçevede, üreticilere yetkili kişiler tarafindan hal kayıt sistemi hakkında gerekli bilgilendirmenin yapılması büyük önem taşımaktadır. Öyle ki, hal kayıt sisteminin iyileşmesi için üreticilerin devletten beklentilerinin neler olduğu sorulduğunda, üreticilerin büyük bir kısmı "bilgilendirme ve eğitim” cevabını vermiştir.

Üreticilerin hal kayıt sistemine kayıt olmasında etkili olan faktörler logit modeli kullanılarak belirlenmiştir. Modelde istatistiki açıdan anlamlı çıkan değişkenler; yaş, eğitim, yıllık gelir, köyün ilçeye uzaklığı ve bireyin akıllı telefona sahip olmasidir.

Çizelge 7 incelendiğinde; üreticinin yaşı arttıkça hal kayıt sistemine kayıt olma olasılığı azalış eğilimi göstermektedir. Yaşlı üreticiler teknolojiyi ve yeni bilgileri takip etmedikleri için hal kayıt sistemine kayıt olmadıkları, genç üreticilerin ise yenilikleri hızlı takip ettikleri için bilgi sahibi oldukları ve sisteme kayıt oldukları gözlenmiş̧tir. Üreticilerin eğitim düzeyi

Çizelge 4. Ürünlerin hal kayıt sistemine bildirim miktarı (Ton)*.

Table 4. Notification amount of crops to wholesale market registration system (Tone).

\begin{tabular}{|c|c|c|c|c|c|c|}
\hline & \multicolumn{3}{|c|}{2016} & \multicolumn{3}{|c|}{2017} \\
\hline & $\begin{array}{c}\text { Patates } \\
\text { Üreticileri }\end{array}$ & $\begin{array}{l}\text { Mandalina } \\
\text { Üreticileri }\end{array}$ & $\begin{array}{c}\text { Şeftali } \\
\text { Üreticileri }\end{array}$ & $\begin{array}{c}\text { Patates } \\
\text { Üreticileri }\end{array}$ & $\begin{array}{l}\text { Mandalina } \\
\text { Üreticileri }\end{array}$ & $\begin{array}{c}\text { Şeftali } \\
\text { Üreticileri }\end{array}$ \\
\hline Üretim miktarı & 475.00 & 120.00 & 57.13 & 585.43 & 171.88 & 73.45 \\
\hline Hale Bildirilen miktar & 475.00 & 103.33 & 48.86 & 582.57 & 146.88 & 68.09 \\
\hline Fark & 0.00 & 16.67 & 8.27 & 2.86 & 25.00 & 5.36 \\
\hline Fark $(\%)$ & 0.00 & 13.89 & 14.47 & 0.49 & 14.55 & 7.30 \\
\hline
\end{tabular}

*Patates üreticilerinin \%28'i, Mandalina üreticilerinin \%16's1, Şeftali üreticilerinin \%48'i cevaplamıştır.

*Answered by $28 \%$ of potato farmers, $16 \%$ of Mandarin farmers, $48 \%$ of peach farmers.

Çizelge 5. Hal rüsumu ve ürün künyesi ile ilgili bilgiler.

Table 5. Information about the wholesale market taxes and crop tag.

\begin{tabular}{|c|c|c|c|c|c|}
\hline & & Patates Üreticileri & Mandalina Üreticileri & Şeftali Üreticileri & Genel \\
\hline \multirow{2}{*}{$\begin{array}{l}\text { Alıcının Hal Rüsumu Adı Altında } \\
\text { Para Alma Durumu* }\end{array}$} & Evet & 14.0 & 12.0 & 38.0 & 21.3 \\
\hline & Hayır & 86.0 & 88.0 & 62.0 & 78.7 \\
\hline \multirow{2}{*}{$\begin{array}{l}\text { Üreticinin Hal Rüsumunu Ödeme } \\
\text { Şekli }\end{array}$} & Tamamını & 57.1 & 50.0 & 89.5 & 75.0 \\
\hline & Yarısını & 42.9 & 50.0 & 10.5 & 25.0 \\
\hline \multirow[t]{2}{*}{ Ürün Künyesi Kavramını Bilme } & Evet & 62.0 & 46.0 & 46.0 & 51.3 \\
\hline & Hayır & 38.0 & 54.0 & 54.0 & 48.7 \\
\hline \multirow[t]{2}{*}{ Ürün Künyesine Sahip Olma } & Evet & 74.2 & 60.9 & 95.5 & 76.3 \\
\hline & Hayır & 25.8 & 39.1 & 4.5 & 23.7 \\
\hline
\end{tabular}

*Person Chi Square 12.474, p 0.002<0.05. 
Çizelge 6. Hal kayıt sistemi hakkında en önemli ve en önemsiz sorunlar.

Table 6. The most and least ımportant problems about the wholesale market register system.

\begin{tabular}{|c|c|c|c|c|}
\hline & En İyi & En Kötü & Fark & Ortalama \\
\hline Üreticilerin bu sistem hakkında bilgisinin olmaması ve bilgi eksikliği & 64 & 7 & 57 & 0.7125 \\
\hline $\begin{array}{l}\text { Denetim yetersizliği (üretilen önemli miktardaki ürünün hal kayıt sistemine } \\
\text { bildirilmemesi) }\end{array}$ & 11 & 5 & 6 & 0.075 \\
\hline $\begin{array}{l}\text { Aracıların hal kayıt sistemini bahane ederek üreticilere verdikleri fiyatı } \\
\text { düşürmeye çalışmaları }\end{array}$ & 28 & 14 & 14 & 0.175 \\
\hline $\begin{array}{l}\text { Üreticilerin bilişim teknolojilerini (bilgisayar, akıllı telefon uygulaması, } \\
\text { vb.) kullanmadaki yetersizlikleri }\end{array}$ & 0 & 19 & -19 & -0.2375 \\
\hline $\begin{array}{l}\text { Hükümetin haller için uygulamaya çalıştığı mevzuatta sürekli değişim } \\
\text { yaşanması }\end{array}$ & 3 & 23 & -20 & -0.25 \\
\hline Hal Kayıt Sisteminin taraflar açısından kullanımının kolay olmaması & 2 & 21 & -19 & -0.2375 \\
\hline Diğer & 1 & 1 & 0 & 0 \\
\hline
\end{tabular}

Çizelge 7. Hal kayıt sistemine kayıt olmayı etkileyen faktörler.

Table 7. The factors affecting registration of wholesale market register system.

\begin{tabular}{|c|c|c|c|c|}
\hline Bağımsız Değişkenler & Katsayı & Ölç. Hata & z-Statistiği & p-değeri \\
\hline Üreticinin Yaşı (yıl) & -0.0404865 & 0.021095 & -1.9192 & $0.0550 * *$ \\
\hline Eğitim & 0.384749 & 0.219012 & 1.7568 & $0.0790 * *$ \\
\hline Toplam arazi miktarı (daa) & -0.00304825 & 0.00337262 & -0.9038 & 0.3661 \\
\hline Y1llık gelir durumu (TL) & 0.432777 & 0.214762 & 2.0151 & $0.0439 *$ \\
\hline Ailedeki birey sayısı (kişi) & 0.0583915 & 0.146496 & 0.3986 & 0.6902 \\
\hline Köyün İlçeye uzaklığı (km) & -0.030261 & 0.0171889 & -1.7605 & $0.0783^{* *}$ \\
\hline İnternete bağlanma durumu & -0.635422 & 0.913342 & -0.6957 & 0.4866 \\
\hline Bilgisayar kullanma durumu & -0.201805 & 0.643291 & -0.3137 & 0.7537 \\
\hline Tarımdışı işi olması & -0.289936 & 0.392321 & -0.7390 & 0.4599 \\
\hline Akıllı telefon olması & 1.37376 & 0.785712 & 1.7484 & $0.0804 * *$ \\
\hline Log-olabilirlik =-86.29806 & McFadden R-kare $=0.159173$ & Gözlem sayısı= 107 & & \\
\hline
\end{tabular}

arttıkça hal kayıt sistemine kayıt olma olasılığı artış eğilimi göstermektedir. Üreticilerin yıllık geliri arttıkça hal kayıt sistemine kayıt olması artış eğilimi göstermektedir. Fakat yıllık gelirin azalma durumunda üreticiler hal kayıt sistemine kayıt olmaktan kaçınmaktadırlar. Bunun nedeni, vergiden kaçınma olarak açıklanabilir. İlçeye uzak olan köyler sosyal ve bilgi bakımından geri planda kaldığı görülmektedir. $\mathrm{Bu}$ sebeple köyün ilçeye uzaklığı arttıkça üreticilerin hal kayıt sistemine kayıt olma durumu azalıș eğilimi göstermektedir. Akıllı telefon yoksunluğu üreticilerin teknolojiden ve bu sebeple yeni oluşan bilgilerden uzaklığını göstermektedir. Dolayısıyla akıllı telefonu olan üreticilerin, olmayan üreticilere göre hal kayıt sistemine kayıt olma olasılığı daha fazladır.

\section{Sonuç ve Öneriler}

Türkiye'de 12 Eylül 1960 tarih ve 80 sayılı Toptancı Halleri Sureti İdaresi Hakkında Kanun ile başlayan yaş meyve ve sebze pazarlaması günümüze kadar çeşitli Kanun, KHK, değişiklik kanunu ve yönetmeliklerle değiştirilmiştir. İzmir ilindeki yaş meyve ve sebze üreticilerinin 5957 say1lı Yeni Hal Kanunu hakkında bilgi düzeylerinin belirlenmesi, kayıt dışı ticaretin ve üreticilerin hal kayıt sistemine bakış açılarının ortaya konulmasını amaçlayan bu çalışmada; üreticilerin sıklıkla kullandığı pazarlama kanallarının komisyoncu ve tüccar olduğu belirlenmiştir. Üreticiler ve komisyoncuları ele alan farklı çalışmalarda da benzer sonuçlara rastlanmıştır.

Çalışmada görüşülen patates, mandalina ve şeftali üreticilerinin büyük bir kısmının hal kayıt kavramını bilmesine rağmen, hal kayıt sistemine kayıtlı olan üretici sayıs1 \%50'yi bile bulmamaktadır. Patates, mandalina ve șeftali üreticileri ile hal kayıt sistemine kayıt olma arasında istatistiksel olarak anlamlı bir fark olduğu tespit edilmiş ve en fazla kayıtlanma oranının \%68 ile şeftali üreticilerinde olduğu belirlenmiştir. Bununla birlikte kayıtlı olan üreticilerinde bildirim yapma oranının oldukça düşük olduğu görülmektedir. Bu durum, 2016 ve 2017 üretim döneminde üretilen ürün miktarı ile hale bildirilen ürün miktarı incelendiğinde de kayıt dışılığın ne kadar fazla olduğunu kanıtlamaktadır. 2017 yılında en fazla kayıt dışılığın \%14.55 oranla mandalinada olduğu tespit edilmiştir. Mandalinayı \%7.30 oranla şeftali, \%0.49 ile de patates takip etmektedir. Literatürde yapılan çalışmalarda da kayıt dışılığın oldukça fazla olduğu ve komisyoncuların kanunen geçersiz belgeler ile kayıt dışı ticarete sebep oldukları tespit edilmiştir.

Hal kayıt sistemine bildirim şekli genel olarak internet üzerinden yapılmaktadır. Bunun için üreticilerin teknoloji kullanımının artması ile birlikte hem bildirim sayısı artacak hem de sistem hakkında yeni çıkan bilgilere erişim kolaylaşacaktır. $\mathrm{Bu}$ amaçla GSM operatörleri tarafindan üreticilere yönelik internet paketi olan hasat dönemlerinde ödemesi yapılabilecek tarifeler geliştirilebilir. $\mathrm{Bu}$ kapsamda üreticiye kolaylık sağlayacak GSM operatörlerini devlet vergi indirimi gibi kolaylıklar sağlayarak teşvik edebilir.

Üreticilerin hal kayıt sistemi konusunda gördüğü en önemli sorunun bilgi eksikliği olduğu tespit edilmiştir. $\mathrm{Bu}$ durumun ortadan kaldırılması ve hal kayıt sisteminin ne demek olduğu, hal kayıt sistemine nasıl kayıt olunacağı ve nasıl bildirim yapılması gerektiğini açıllayan bilgilendirme mesajları gönderilebilir. Örneğin; bu amaçla köy muhtarlıkları tarafından 
bilgilendirme broşürleri vb. dağıtılabilir. Zaman zaman komisyoncular ile üreticilerin bir araya getirilerek bilgilendirme ve eğitim faaliyetleri yapılabilir. Hal kayıt sistemine kayıt olmayı yaş, eğitim, gelir gibi faktörlerin etkilediği tespit edilmiştir. Yapılacak bilgilendirme toplantılarında yaş gruplarına göre farklı eğitimler verilebilir. Yaşlı üreticilerin var ise çocuklarına yönelik eğitimler düzenlenerek, yaşlı üreticilerin hak kaybına uğramaması sağlanabilir. $\mathrm{Bu}$ çalışmanın sonuçlarının, hal kayıt sisteminin sorgulanması ve iyileştirilmesi açısından karar alıcılara önemli bulgular sağlayacağı düşünülmektedir.

\section{Kaynaklar}

Adanacıoglu H, Yercan M (2012) Yeni Hal Kanununun Tarım Kesimine Olan Muhtemel Etkilerinin Değerlendirilmesi. 10. Ulusal Tarım Ekonomisi Kongresi 5-7 Eylül 2012: 844-845.

Apalı A, Bozcu M (2018) Hal Komisyonculuğunda Belge Düzeni Açısından Vergi Usul Kanununun Uygulanmasında Ortaya Çıkan Farklılıkların Araştırılması: Antalya Toptancı Hali Örneği. Diyalektolog Ulusal Sosyal Bilimler Dergisi 19: 467-478.

Aydın Can B, Engindeniz S (2018) Tarım Ürünlerinin Pazarlanmasında Toptancı Hallerinin Rolü ve Önemi: Kocaeli Merkez İlçe Toptancı Hali Örneği. Selçuk Tarım ve Gıda Bilimleri Dergisi 32(3): 266273.

Aysoy C, Kırlı DH, Tümen S (2015) Taze Meyve-Sebze Tedarik Zincirindeki Engelleri Azaltıcı Tedbirlerin Fiyatlar Üzerindeki Etkisi. TCMB Ekonomi Notları 3: 1-12.

Canik F, Alparslan Y (2010) Türkiye'de Yaş Meyve ve Sebze Pazarlaması ve Toptancı Halleri. Tarımsal Ekonomi ve Politika Geliştirme Enstitüsü 11:2-8.

Çoşkun H (2014) Aydın İlinde Yaş Sebze ve Meyve Toptancı Hallerinin İncelenmesi. Yüksek Lisans Tezi, Adnan Menderes Üniversitesi Fen Bilimleri Enstitüsü, Aydın.

Çoşkun MH, Tunalığlu R (2015) Aydın İlinde Yaş Sebze ve Meyve Toptanc1 Hallerinin İncelenmesi. Adnan Menderes Üniversitesi Ziraat Fakültesi Dergisi 12(2): 83-92.

Demirbaş N (2001) Türkiye'de Toptancı Halleri ile İlgili Yasal Düzenlemelerin Meyve-Sebze Üretim ve Pazarlama Politikalarının Başarısı Üzerine Etkileri: İzmir İli Örneği. Türkiye Ziraat Odaları Birliği, İzmir, s. 1-2.

Eraktan G (1997) Avrupa Birliğinde Meyve ve Sebze Sektörüne Yönelik Politikalar ve Türkiye'nin Uyumu. Bahçe Ürünlerinde Muhafaza ve Pazarlama Sempozyumu, Atatürk Bahçe Kültürleri Merkez Araştırma Enstitüsü, Yalova: 17-22.

Giray FH (1998) Yeni Hal Yasası Gerçekten Yeni Bir Yasa mı?. TürkKooperatif Ekin Dergisi 52-56.

Gözener B, Sayılı M (2011) Tokat İli Merkez İlçede Toptancı Halindeki Komisyoncuların Yeni Hal Yasası Hakkındaki Görüşleri. Gaziosmanpaşa Üniversitesi Ziraat Fakültesi Dergisi 28(2): 227 235.

Hadimli H, Bulut İ (2004) Antalya'da Sebze-Meyve Ticareti ve Antalya Toptancı Hali'ne Coğrafi Bir Yaklaşım. Doğu Coğrafya Dergisi 11: 261-282.

İzmir Valiliği (2017) www.izmir.gov.tr. Erişim 19 Mayıs 2017.

Ormeci Kart CM, Abay CF, Gungor S, Ozer Z (2017) Seed Supply and Seed Preferences of Potato Farmers: Nigde Central and İzmir Ödemis Provinces. Scientific Papers Series Management, Economic Engineering in Agriculture and Rural Development 17(2): 239-250.

Ölmez S, Demirörs MO (2015) Yeni Hal Yasası Üzerine Bir Derleme. Türk Bilimsel Derlemeler Dergisi 8(2): 59-65.

Sayın C, Mencet MN (2007) Hal Yasası'nın Yaş Meyve ve Sebze Pazarlamasındaki Etkinliğinin Tartışılması. GAP V. Tarım Kongresi, 17-19 Ekim, Urfa.
Yılmaz S, Yılmaz İ (2002) Türkiye Yaş Meyve ve Sebze Pazarlamasında Toptancı Hal Sisteminin Değerlendirilmesi: Antalya Büyükşehir Belediyesi Toptancı Hali Örneği. Türkiye V. Tarım Ekonomisi Kongresi, Erzurum: 292-299. 